\title{
Strategic Consolidation under Formula Apportionment
}

\author{
THIESS BUETTNER \\ NADINE RIEDEL \\ MARCO RUNKEL
}

CESIFO WORKING PAPER NO. 2484

CATEgory 1: Public FinAnCE

DECEMBER 2008

\footnotetext{
An electronic version of the paper may be downloaded

- from the SSRN website: www.SSRN.com

- from the RePEc website: - from the CESifo website: 


\title{
Strategic Consolidation under Formula Apportionment
}

\begin{abstract}
This paper argues that profit-shifting activities of multi-jurisdictional enterprises (MJE) are maintained under a tax system of consolidation and formula apportionment (FA). A theoretical model discusses how an MJE can exploit its impact on the definition of the consolidated group strategically. The analysis shows that the MJE will run individual affiliates as separate un-consolidated firms for tax purposes if intra-group tax-rate differences, and thereby potential gains from profit-shifting, are large. We test this prediction using confidential firm-level tax-return data for the local business tax in Germany. The identification strategy exploits a quasi experiment derived from a major company tax reform in 2001 that reduced the costs associated with separating out individual affiliates. Our results show that, evaluated at the sample mean, an increase in the tax-rate variance among the MJE's affiliates by one standard deviation reduces the number of consolidated affiliates by $20 \%$.
\end{abstract}

JEL Code: H32, H73.

Keywords: corporate taxation, formula apportionment, micro data.

Thiess Buettner

Ifo Institute for Economic Research at the

University of Munich

Poschingerstrasse 5

81679 Munich

Germany

buettner@ifo.de

Nadine Riedel

Centre for Business Taxation

Saïd Business School

University of Oxford

Park End Street

UK-Oxford OXI $1 H P$

nadine.riedel@sbs.ox.ac.uk
Marco Runkel

Faculty of Economics and Management

University of Magdeburg

Postbox 4120

39016 Magdeburg

Germany

marco.runkel@ovgu.de

October 2008

We thank participants of the Meeting of the Association for Public Economic Theory (APET) in Seoul for helpful comments. 


\section{Introduction}

The last years have witnessed an increasing interest in the international dimension of taxing multinational firms. The current situation is characterized by a complex system of bilateral double-taxation treaties applying separate accounting (SA) rules that treat multinational affiliates as distinct entities. ${ }^{1}$ These rules, however, are increasingly criticized by politicians and researchers because they open up multinational tax planning opportunities. Specifically, SA is criticized since it implies that multinationals which face international differences in corporate taxation minimize their tax burden by shifting taxable profits to low-tax countries (for a survey on empirical evidence see Devereux, 2006). This puts pressure on the corporate taxation system since high-tax countries face substantial revenue losses and multinational profit-shifting opportunities discriminate against companies that operate on a domestic scale only.

As a possible alternative to SA, a system of profit consolidation in combination with formula apportionment (FA) is discussed (e.g., Weltzer, 1995, and Mintz, 1999), which is applied at the subnational level in several countries, for example, in the US, Canada, Germany and Switzerland. The debate about relative merits of FA versus SA has recently been intensified in the European context, where the European Commission in 2001 proposed to introduce FA within EU borders (see Fuest, 2008, for a discussion of the reform's details). Under FA, profit is consolidated at the group level and apportioned to the affiliates according to a formula that measures the affiliates' relative corporate activities. Theoretically, group-wide consolidation should thereby abolish profit-shifting incentives. This effect is often perceived as a major advantage of applying FA.

Contrary to this presumption, our paper shows that profit-shifting incentives remain important under FA. We argue that a particular problem faced by FA is that profit shifting within the corporate group is only abolished if all group affiliates of the MJE are consolidated. If MJEs, in contrast, have some leeway in deciding whether affiliates are included in the basis of consolidation, they might strategically refrain from consol-

\footnotetext{
${ }^{1}$ See also the OECD Model Convention (OECD, 1992).
} 
idation to preserve profit-shifting opportunities. The appropriate group definition (i.e. which affiliates belong to a corporate group) is a well-known problem in almost all FA systems. In the US case, for example, a group is defined either by a legal criterion ('ownership share') or by an economic criterion ('unitary business'). Under the legal group definition it is obvious that corporations can distort their ownership structure in order to maintain profit-shifting channels to economically, but not legally, related affiliates. Comparable manipulation opportunities seem to exist under the economic group definition as is suggested by a large number of litigations in the US to determine the relation of affiliates to corporate groups (e.g. Weiner, 2006). ${ }^{2}$

In order to address the strategic choice with regard to consolidation of affiliated firms, we develop a simple theoretical model of a MJE that runs affiliates in two different jurisdictions and that decides about whether or not to consolidate these affiliates. By comparing the maximized after-tax profit under the two alternatives, we identify a basic trade-off determining the consolidation decision. On the one hand, exclusion of affiliates is associated with costs. This comprises costs caused by changes in the corporate structure which lower the degree of economic and financial integration to an extent that allows the MJE to tax an affiliate as a separate entity. For instance, agency costs with regard to the management of the separate affiliate may arise. Also, loss offset opportunities between the affiliates are reduced, so the expected tax burden increases, ceteris paribus. On the other hand, non-consolidation has the benefit of maintaining profit-shifting opportunities. This benefit, and thus the incentive for nonconsolidation, turns out to be the more important the larger the dispersion of statutory tax rates within the whole corporate group.

In a second step, we test empirically whether this characterization of a strategic consolidation decision can be used to predict the observed structure of consolidated firms. Our testing ground is the German local business tax that is levied at the municipal level and significantly contributes to the company tax burden in Germany. If a MJE

\footnotetext{
${ }^{2}$ There exist many alternative criteria used to determine whether an affiliate economically belongs to a group or not. While it is undisputed that such criteria improve the group definition for tax purpose, the scientific debate about the pros and cons of the criteria suggests that they are not perfect and still prone to tax-planning activities of MJEs (e.g. Weiner, 2006).
} 
holds affiliates in several municipalities, an FA scheme applies that renders group profit to be consolidated at the national level and prescribes apportionment according to the affiliates' relative payroll shares. However, as in the US case, at least in the time period analyzed below, the German FA scheme applies only conditional on appropriate legal, financial, and economic ties between the entities. Since a group's ownership pattern as well as the economic and financial connections are outcomes of firm decisions, MJEs enjoy some discretion with regard to the inclusion of affiliates in the unitary tax assessment and may thus - within certain boundaries - choose whether affiliates are subject to $\mathrm{SA}$ or FA regulations.

To identify tax determinants of the MJEs' choice of the consolidated group, we exploit a quasi experiment that arises from a recent change in the German tax law associated with a comprehensive company tax reform in 2001. This reform significantly reduced the cost associated with non-consolidation under the business tax because loss-offset opportunities have been enhanced even for those firms that are not-consolidated. Given the reduction in the cost of non-consolidation, the reform allows us to test whether, in fact, consolidated firms that face significant profit-shifting opportunities tend to reorganize in a way that is consistent with a strategic choice of consolidation.

The empirical analysis employs a unique dataset that comprises confidential tax return data for the whole population of firms subject to the German local business tax in the years 1998 and 2001. Our results indicate behavioral patterns that are in line with our theoretical predictions. More specifically, MJEs with a large variation in business-tax rates across group affiliates display a reduction in the number of consolidated affiliates between 1998 and 2001 compared to MJEs with a small variation in tax rates across group affiliates. This result turns out to be robust against the inclusion of various control variables, characterizing the corporate group and the economic conditions in the hosting communities. Evaluated at the sample mean, we find that an increase in the variance of the statutory tax-rates among the affiliates of an MJE by one standard deviation reduces the number of consolidated affiliates by $20 \%$. This sizeable effect points to an important strategic component in the MJEs' consolidation decision.

Our paper mainly adds to two strands of the economic literature. First, it contributes 
to the discussion of the pros and cons of different corporate taxation schemes for MJEs. The comparison of SA and FA goes back to early papers by McLure (1980) and Gordon and Wilson (1986) who show that FA may lead to distortions in firm behavior similar to SA. Recent papers by Anand and Sansing (2000), Eggert and Schjelderup (2003), Sørensen (2004), Wellisch (2004), Kind et al. (2005), Nielsen et al. (2006), Riedel and Runkel (2007), Pinto (2007), Pethig and Wagener (2008) and Eichner and Runkel (2008) focus on the welfare implications of corporate taxation under SA and FA. Moreover, although the empirical evidence is still limited, the recent years have seen the emergence of a literature that empirically quantifies the distortions and economic outcomes of corporate taxation under FA. Examples are papers by Goolsbee and Maydew (2000), Buettner (2003), Mintz and Smart (2004), Fuest et al. (2007) and Riedel (2008). Nevertheless, to the best of our knowledge neither the existing theoretical nor the existing empirical papers have analyzed the endogenous consolidation decision of MJEs under FA.

Additionally, our paper relates to a small literature that investigates how corporate taxation distorts the organizational structure of MJEs. Desai et al. (2004) analyze the determinants of partial ownership of foreign US affiliates. Their evidence indicates that whole ownership is most common when firms benefit from worldwide tax planning opportunities. Weichenrieder and Smart (2007) in turn provide evidence that MJEs distort the corporate organizational structure by using conduit and holding companies to reduce their corporate tax burden. Huizinga and Voget (2006) present results that indicate ownership patterns within multinational entities to be determined by profit tax rates and withholding taxes. Bucovetsky and Haufler (2008) discuss the consequences of preferential tax regimes for multinationals when firms can choose their multinational structure. However, also this literature does not focus on the consolidation decision of MJEs under an apportionment taxation system.

The paper is structured as follows. Section 2 presents the theoretical model underlying our estimation strategy which is explained in detail in Section 3. Section 4 contains a description of the data and provides basic descriptive statistics. Section 5 outlines the estimation methodology, Section 6 presents the results, and Section 7 concludes. 


\section{A Simple Theoretical Model}

In order to address the strategic choice of a MJE with regard to consolidation of affiliated firms, we develop a simple model of the consolidation decision of a single MJE. Suppose the MJE has affiliates in two jurisdictions. The jurisdictions are labeled by $a$ and $b .^{3}$ Each affiliate earns the same before-tax profit denoted by $\pi$. This beforetax profit is treated as given, which amounts to assuming that the MJE has already decided on its investment and employment in both affiliates. This assumption allows us to focus on the consolidation decision of the MJE which is the main interest of our analysis.

We consider corporate income taxation according to the FA principle with tax base consolidation and unitary tax assessment. As already discussed in the Introduction, however, even under such a taxation system MJEs have some discretion with regard to the inclusion of affiliates into the consolidated group. Put differently, the MJEs have in fact some choice between FA and SA taxation. This choice is explicitly considered in our theoretical model, that is concerned with the strategic decision of the MJE to consolidate the two affiliates (FA) or not (SA).

On the one hand, the MJE will incur additional costs $\gamma>0$ if it does not consolidate the affiliates. These non-consolidation costs arise, for example, from changes in the corporate structure that are necessary in order to run an affiliate as a separate entity for tax purposes. In the institutional context of the empirical analysis below, the MJE would have to change the organizational, economic, and financial integration of the firms. As a consequence, agency costs with regard to the management of the affiliates may arise. Also, loss-offset opportunities between the consolidated group and the separated affiliate will be reduced which increases the expected tax burden.

On the other hand, when the two affiliates are not consolidated, the MJE may shift profit from one jurisdiction to the other. Typical channels of profit shifting involve the manipulation of transfer prices of intra-firm trade, the use of internal debt and

\footnotetext{
${ }^{3}$ Note that for our purpose, it is irrelevant whether the headquarter of the MJE is located in jurisdiction $a$ or jurisdiction $b$.
} 
the manipulation of the distribution of overhead cost (e.g., Devereux, 2006). However, since the specific channel of profit shifting is immaterial for our purpose, we simply consider the total amount of profit shifted - denoted by $s$. If $s>0$, the MJE shifts profit from jurisdiction $a$ to jurisdiction $b$. For $s<0$ shifting takes place the other way round. Profit shifting is not costless to the MJE. It causes concealment costs denoted by $C(s)$. These costs reflect, for example, the MJE's expenses for tax lawyers or the risk of additional tax payments if tax authorities deny deductions. The concealment cost function satisfies $\operatorname{sign}\left\{C^{\prime}(s)\right\}=\operatorname{sign}\{s\}$ and $C^{\prime \prime}(s)>0$, i.e. it is U-shaped with the minimum at the point where the MJE forgoes profit shifting. Moreover, we assume $C(0)=0$ so that concealment costs are zero if the MJE does not engage in shifting.

The MJE will not consolidate if and only if the maximized net profit of doing so is larger than in the case of consolidation. Hence, we have to compare the maximized net profit in the two cases. Let us start with the case where the MJE does not consolidate. The after-tax profit (before subtracting the non-consolidation cost $\gamma$ ) then reads

$$
\pi_{s}=\left(1-t_{a}\right)(\pi-s)+\left(1-t_{b}\right)(\pi+s)-C(s),
$$

where $t_{a}$ and $t_{b}$ represent the corporate tax rates of jurisdiction $a$ and jurisdiction $b$, respectively. Equation (1) shows that without consolidation the two affiliates are taxed separately and the MJE may use profit shifting to increase the tax base in one jurisdiction and reduce the tax base in the other jurisdiction. The first-order condition with respect to optimal profit shifting $s$ is given by

$$
C^{\prime}(s)=t_{a}-t_{b}
$$

Hence, the MJE determines profit shifting such that the marginal concealment cost equals the marginal gain from profit shifting represented by the tax rate differential. If jurisdiction $a$ is the high-tax jurisdiction, the marginal concealment cost will be positive and profit shifting takes place from jurisdiction $a$ to jurisdiction $b(s>0)$. If jurisdiction $b$ is the high-tax jurisdiction, profit shifting will be the other way round $(s<0)$. Equation $(2)$ determines the MJE's optimal profit shifting as function of the tax rate differential, i.e. $s=S\left(t_{a}-t_{b}\right)$ with $S^{\prime}\left(t_{a}-t_{b}\right)=1 / C^{\prime \prime}>0$. Profit shifting is therefore higher the larger the tax rate differential between the two jurisdiction. 
Inserting into (1) gives the MJE's maximized after-tax profit

$$
\pi_{s}^{*}=\left(2-t_{a}-t_{b}\right) \pi+\left(t_{a}-t_{b}\right) S\left(t_{a}-t_{b}\right)-C\left[S\left(t_{a}-t_{b}\right)\right]
$$

In order to obtain the net payoff of the MJE in case of non-consolidation, we have to subtract from (3) the non-consolidation $\operatorname{cost} \gamma$.

If the MJE consolidates its affiliates, profit is taxed according to the FA principle. The consolidated tax base equals $2 \pi$. This consolidated tax base is assigned to the two jurisdictions according to a formula that - in the practice of FA - may contain capital, payroll, and/or sales shares of the MJE in the respective jurisdiction. Since we assume that the MJE has already decided on investment and employment in both affiliates, in our model the apportionment factors are fixed. More specifically, suppose the share $\alpha \in[0,1]$ of the consolidated tax base is assigned to jurisdiction $a$, while jurisdiction $b$ receives the share $1-\alpha$ of the consolidated tax base. The MJE's after-tax profit in case of consolidation can then be written as

$$
\pi_{f}=2 \pi\left[1-\alpha t_{a}-(1-\alpha) t_{b}\right]-C(s)
$$

Because tax bases are consolidated, there is no gain from shifting profit from one affiliate to the other. Thus, the MJE simply chooses the amount of profit shifting that minimizes concealment costs, i.e. $s=0$ so $C(s)=0$. Inserting into Equation (4) yields

$$
\pi_{f}^{*}=2 \pi\left[1-\alpha t_{a}-(1-\alpha) t_{b}\right]
$$

Equation (5) gives the MJE's maximized profit in the case where it decides to consolidate the two affiliates.

In order to characterize the MJE's consolidation decision we have to compare the expression for the maximized profit in Equations (3) and (5), taking into account the non-consolidation cost $\gamma$. Hence, the MJE will not consolidate if and only if

$$
\pi_{s}^{*}-\gamma>\pi_{f}^{*}
$$

or, equivalently,

$$
2 \pi\left[\frac{t_{a}+t_{b}}{2}-\alpha t_{a}-(1-\alpha) t_{b}\right]<\left(t_{a}-t_{b}\right) S\left(t_{a}-t_{b}\right)-C\left[S\left(t_{a}-t_{b}\right)\right]-\gamma .
$$


With the simplifying assumption that the tax burden without profit shifting is the same under $\mathrm{SA}$ and $\mathrm{FA}^{4}$, i.e. $\left(t_{a}+t_{b}\right) / 2=\alpha t_{a}+(1-\alpha) t_{b}$, this condition can be expressed as

$$
\left(t_{a}-t_{b}\right) S\left(t_{a}-t_{b}\right)-C\left[S\left(t_{a}-t_{b}\right)\right]>\gamma
$$

This inequality states that the MJE will not consolidate if the total gain from profit shifting (LHS) exceeds the consolidation costs (RHS). It is immediately seen that the gain from profit shifting on the LHS is U-shaped in the tax differential with a minimum at the point where the tax rate differential vanishes. ${ }^{5}$ Hence, we obtain the following

Proposition. Consolidation of the MJE becomes less likely the lower the non-consolidation costs $\gamma$ and the higher the tax rate differential $t_{a}-t_{b}$ in absolute terms.

The intuition of the result with respect to the decline in the non-consolidation costs $\gamma$ is obvious. With respect to the tax rate differential between the affiliates, it holds that the larger this differential, the larger are the MJE's gains from profit shifting activities, and the advantage of taxing the affiliates separately becomes relatively more important to the MJE than the non-consolidation costs.

\section{Investigation Approach}

According to the above theoretical discussion, if MJE's have some leeway in deciding whether affiliates are included in the basis of consolidation, this decision might be taken strategically. While there will be important cost of non-consolidation, to run an affiliate

\footnotetext{
${ }^{4}$ It is well known that with endogenous apportionment factors the firms' investment and employment decisions are distorted by consolidation and apportionment. See the studies referred to in the Introduction. These distortions are absent in our model since we assume a fixed apportionment factor. Symmetry of the earned pre-tax profit $\pi_{a}=\pi_{b}=\pi$ suggests to set $\alpha=1 / 2$. We chose this modeling strategy for expositional simplicity. It is straightforward to show that even with additional distortions under FA our results hold due to the common perception that the relocation of pre-tax profit to low-tax countries is substantially easier via profit shifting under SA than via a distortion of the apportionment factors under FA (see e.g. Mintz and Smart (2004) for empirical evidence).

${ }^{5}$ Formally, define $F\left(t_{a}-t_{b}\right):=\left(t_{a}-t_{b}\right) S\left(t_{a}-t_{b}\right)-C\left[S\left(t_{a}-t_{b}\right)\right]$. Using $(2)$ then yields $F^{\prime}\left(t_{a}-t_{b}\right)=$ $S\left(t_{a}-t_{b}\right) \gtreqless 0$ if and only if $t_{a}-t_{b} \gtreqless 0$.
} 
as a separate firm for tax purposes might preserve important profit-shifting opportunities. A decline in the non-consolidation costs is predicted to provide an incentive to exclude affiliates from group consolidation, and this incentive will be particularly relevant for MJEs facing large intra-group tax rate differentials.

To empirically test this prediction, we investigate FA in the context of the German local business tax. This tax is levied at the municipal level while the tax law that determines the tax base definition is chosen at the national level. Thus, local autonomy is confined to setting the tax rate, tax administration including the tax apportionment is the responsibility of the state government. Moreover, for MJEs, i.e. firms operating affiliates in more than one municipality, a FA system with payroll apportionment applies. Accordingly, the MJE's taxable income is consolidated at the national level and is apportioned to the individual entities according to the relative payroll share.

Subject to the German local business tax are incorporated and un-incorporated firms, as well as individual enterprises. The local business tax burden on profits allocated to a municipality is determined by the municipality's business tax rate. This is measured in local business tax points and ranges from 0 to 900 points in our data, with an average of 325 points. To calculate a firm's actual tax burden, pre-tax profits are commonly multiplied by a percentage value of $5 \%$ and by the municipality's local business tax rate. Taking account of the self-deductibility of the business tax, the resulting statutory tax rate on profits varies between zero and $31 \%$, with a mean of about $14 \%$.

As with other FA systems, MJEs under the German local business tax scheme have some discretion with regard to the decision whether to consolidate a certain affiliate or not. The extent to which they may strategically manipulate the consolidation thereby depends on the costs associated with separate assessment of a corporate affiliate (the parameter $\gamma$ in our theoretical model). As noted in the Introduction, legal and economic restrictions play a critical role in this context. To separate out individual affiliates for purposes of the business tax requires a re-organization of the group with respect to the ownership structure and the economic and financial relations between the entities. This re-organization is associated not only with adjustment cost but may also reduce the efficiency of management processes and increase agency costs with regard to the 
management of the separated affiliates. Moreover, separating out affiliates implies that full loss offset is no longer possible. If an affiliate is consolidated within a corporate group and earns a negative profit, theses losses completely offset the positive profits earned by other affiliates in the calculation of the MJE's local business tax bill. In contrast, if an affiliate is not consolidated under FA regulations and experiences losses, these may not offset profits earned elsewhere and hence they do not reduce the MJE's tax burden. To separate out individual affiliates is therefore particularly costly as these loss-offset opportunities are limited under SA, if not completely ruled out.

Against this background, the empirical analysis exploits an exogeneous variation in the German tax law that significantly reduced the costs associated with taxing an affiliate as a separate firm for purposes of the local business tax. In 2001, the German government implemented a broad company tax reform. Although the reform did not directly alter the consolidation rules for the purposes of the local business tax, it provided German MJEs with new opportunities for loss offset also with firms that are not consolidated for purposes of the local business tax and taxed as separate entities. ${ }^{6}$ The creation of the enhanced loss-offset opportunities thus decreased significantly the cost of strategically separating some of their affiliates from the rest of the group for purposes of the local business tax. Put differently, after the reform the MJE may on the one hand reap tax savings from a separate assessment of affiliates for local business tax purposes by exploiting profit-shifting opportunities. On the other hand, due to the reform this separate assessment does not automatically imply that the MJE has to

\footnotetext{
${ }^{6}$ This effect of the 2001 reform arises due to the interaction between the consolidation rules for the federal corporation tax and the local business tax. Prior to 2001, the consolidation regulations were basically the same for purposes of both the federal corporation tax and the local business tax requiring a substantial financial, organizational, and economic integration (see Herzig, 2003). In 2001, however, consolidation requirements for purposes of the federal corporation tax have been facilitated substantially, while the requirements for the business tax remained unchanged. This opened up the opportunity to reorganize the MJE and separate out affiliates for local business tax purposes while consolidating for the calculation of the federal corporate income tax (e.g., Kirsch and Grube, 2001). A subsequent reform in 2002 then synchronized the consolidation rules for the local business tax with the relaxed regulations for federal corporate tax purposes (Herzig, 2003). While this has facilitated the choice between FA and SA and has opened up further profit-shifting opportunities (e.g., Raedler, 2003) the partial loss-offset opportunity that was created by the 2001 reform was abolished.
} 
forgo all benefits from a loss-offset between its affiliates.

Presuming, therefore, that the cost of excluding affiliates from a group's basis of consolidation has been lowered substantially in 2001, we predict, in line with the theoretical analysis, that the incentive to exclude affiliates increases with profit-shifting opportunities that arise from statutory tax-rate differentials within the group.

\section{Data Set and Sample Statistics}

We test for strategic consolidation using a unique dataset provided by the German Statistical Offices at the federal and state level. The data contains the confidential tax return data for the whole population of German corporations that are subject to local business taxation. The information is gathered directly from German tax authorities and is available for the years 1998 and 2001.

The dataset comprises all German corporations that are liable to the local business tax and includes information about the capital stock, payroll, industry, multi-jurisdictional status (multi-jurisdictional vs. uni-jurisdictional firms), legal form (incorporated vs. un-incorporated firms), taxable profits and characteristics of the firms' hosting locations. Since we are interested in investigating corporate tax effects on the MJEs' consolidation decision, we restrict our attention to entities which operate affiliates including branches in several communities and are henceforth subject to FA regulations. ${ }^{7}$ One major advantage of the data is that it allows us to identify all group affiliates which are consolidated under FA regulations. In order to determine tax effects on the number of consolidated affiliates between 1998 and 2001, we restrict attention to those MJEs for which data is available for both sample years. The resulting dataset covers 50, 342 groups. ${ }^{8}$

\footnotetext{
${ }^{7}$ Note, however, that affiliates and branches may both be consolidated with the group or taxed separately under FA regulations.

${ }^{8}$ The cross sections for 1998 and 2001 are linked by the respective group's tax account identifier which may potentially change over time, mainly in the course of tax office restructuring or headquarter relocations to other jurisdictions or in larger cities even through the relocation to other quarters. While
} 
Table 1 presents basic sample statistics for the corporate groups in our data set. In 1998, the average number of affiliates which are consolidated under FA rules is calculated with 4.1 affiliates for the MJEs in our data set. Between 1998 and 2001 this number increases by 0.11. Calculating the average growth rate in the number of consolidated affiliates for the same time period yields a figure of $5.47 \%$. This average trend in firm numbers possibly reflects a host of different trends in the German economy. This includes the macroeconomic performance of the German economy, structural changes in the industry composition, but also business cycle effects will be important.

However, our theory suggests that given the reduction in the cost of non-consolidation the development in the number of consolidated affiliates should also depend on the opportunities for profit shifting under non-consolidation. Specifically, the rate of growth in this time period should be inversely related to the variation in the local business tax rates across affiliates since this determines the potential gains from profit shifting. To measure the variation of the statutory tax rates, we employ two alternative indicators. First, we calculate the variance of the distribution of the business tax rate within each multi-jurisdictional group prior to the reform in 1998. The average variance measure in local business tax points is thereby determined to be 950.35 and exhibits a considerable variation across groups. Second, we define a measure of the tax-rate variation that is calculated as the ratio of the business tax points at the 90th percentile of the group's tax distribution over the business tax points at the 10th percentile of the group's tax distribution in 1998. The average of this measure is calculated with 1.1534 and indicates that the business tax rate at the 90th percentile of the tax distribution exceeds the tax rate at the 10th percentile by a factor of 1.15 .

We also control for characteristics of the groups' hosting municipalities as well as for several firm characteristics. The sample statistics for these variables are also presented in Table 1. The calculation of averages for hosting municipalities' characteristics is based on data from the German Statistical Offices' REGIOSTAT data base. We calculate unweighted average values for the number of inhabitants, the number of employees and the average unemployment rate for affiliates of an MJE in 1998. Table 1 indicates this results in a reduction of the sample size it mainly constitutes random sample selection that is innocuous for our analysis. 
that the multi-jurisdictional groups in our dataset are on average located in relatively large municipalities with 104, 423 inhabitants and 48, 516 employees, and face an unemployment rate of $12.9 \%$.

Moreover, the groups' average capital stock in 1998 is calculated with 8.3 million Deutsche Mark (DM) or, approximately, 4 million Euros. The MJEs' average pre-tax profits in turn are substantially lower and measured with 56, 467 DM. Additionally, the descriptive statistics indicate a considerable heterogeneity between the consolidated affiliates of the MJEs in our sample with respect to size, profitability, and apportionment shares. Analogous to the calculation of the intra-group tax spreading measures, we employ two measures, the variance and the ratio of the 90th over the 10th percentile of the intra-firm distribution, in order to capture how the capital stock, pre-tax profits, the relative payroll shares, and capital intensity vary across group affiliates in 1998. Since the variance calculation exhibits similar findings, Table 1 in the Appendix reports the descriptive statistics for the 90/10 ratio only. The 90/10 ratio of the affiliates' capital stock points to a considerable heterogeneity between affiliates. A similar picture emerges with regard to the variation of pre-tax profits, the relative payroll share, and the capital intensity in 1998. All reported ratios are relatively large and thus indicate that the groups in our data set comprise very heterogeneous affiliates which substantially differ with regard to size, profitability and capital intensity of production.

\section{Estimation Methodology}

Based on the data set described in the previous section, we empirically assess whether - in line with our theory - a large variation in statutory tax rates across multijurisdictional affiliates is indeed associated with a tendency to exclude affiliates from consolidation in 2001, when the cost of non-consolidation have been decreased substantially. Formally, we estimate the following model

$$
\widehat{n}_{i}=\beta_{0}+\beta_{1} v_{i}+\beta_{2} \log n_{i}+\beta_{3} x_{i}+\epsilon_{i}
$$

whereas $\widehat{n}_{i}$ depicts the growth rate in the number of consolidated affiliates of MJE $i$ between 1998 and 2001 and $v_{i}$ symbolizes the intra-firm corporate tax rate variation in 
1998. Rather than predicting the number of firms in 2001, the model is concerned with the development of the number of affiliates relative to the base year 1998. As explained in the previous section, we employ two alternative measures to capture the tax rate distribution within a group: the group's tax-rate variance in 1998 and the ratio of the business tax rate at the $90^{\text {th }}$ percentile of the intra-firm tax distribution in 1998 over the business tax rate at the $10^{\text {th }}$ percentile. Our model predicts that the larger the variation in the statutory tax rates across affiliates the larger are possible profit-shifting gains if affiliates are taxed separately from the rest of the corporate group. Hence, we expect $\beta_{1}<0$.

Our analysis controls for several group characteristics. Thus, we include the number of affiliates $n_{i}$ that are consolidated under FA regulations in 1998. Additionally, we account for various other variables that may exert an influence on the growth rate of the number of consolidated group affiliates. Since size and profitability may be important, we include each group's stock of capital, profitability, and capital intensity in 1998 as control variables. To account for structural differences between groups, we include a full set of industry dummies at the two-digit NACE code and dummies for different legal forms (individual firms, non-incorporated firms and incorporated firms).

Moreover, we control for average characteristics of the MJE's hosting communities like the number of inhabitants, the number of employees and the unemployment rate in 1998. These variables capture some characteristics at the local or regional level, that might well be correlated with the change in firms numbers. Finally, it seems reasonable to control for the variation in other firm characteristics across subsidiaries to test whether the estimated effect simply picks up other types of heterogeneity between affiliates. Thus, we include control variables in our estimation equation for the variation in the affiliates' relative payroll share in 1998 as well as for the variation in capital stock, pre-tax profits, and capital intensity across affiliates in 1998. The calculation of these measures of variation thereby follows the calculation methodology for the tax-rate variable. Hence, as a measure of the variation we calculate the variance across group affiliates and the ratio of the 90th over the 10th percentile of the variable's intra-group distribution. 
In our baseline regression, we estimate Equation (9) based on OLS methodology. However, the change in the number of consolidated affiliates is small for most groups in our sample. More than $50 \%$ of the groups in our sample do not observe a change in the number of consolidated affiliates between 1998 and 2001 and less than $10 \%$ of the groups observe a change in the number of consolidated affiliates by more than 1 . This suggests to check whether the results are robust against the use of an alternative limited-dependent variable model. For this purpose we construct a categorial variable depicting whether the number of affiliates has increased, stayed constant, or declined and apply an ordered probit model.

\section{$6 \quad$ Results}

This section presents our estimation results. Throughout all regressions the unit of observation is the multi-jurisdictional group. Table 2 displays the results of our baseline OLS regression where the tax-rate variation $v_{i}$ is captured by the variance across consolidated group affiliates. Heteroskedasticity robust standard errors are reported in parentheses below the coefficient estimates. Specification (1) regresses the growth rate in the number of consolidated affiliates on the group's tax-rate variance and on the number of consolidated group affiliates in 1998. As predicted by theory, the variance of the statutory tax rates exerts a significantly negative influence on the number of consolidated affiliates. Evaluated at the sample mean, the coefficient estimate suggests that an increase in the tax variance measure by one standard deviation reduces the growth rate of the number of consolidated affiliates by $17 \% .^{9}$

In specification (2) we additionally account for industry dummies to capture industry specific differences in the development of affiliate numbers. In specification (3) we include a full set of control variables for the groups' legal form and a dummy variable that captures effects of so called integrated corporate groups which do not only comprise

\footnotetext{
${ }^{9} \mathrm{An}$ increase in the tax variance measure by one standard deviation $(=1631.8$, cf. Table 1$)$ reduces the growth rate of the number of consolidated affiliates by 0.95 percentage points $(=1631.8$. $0.0583 / 10,000$, cf. Specification (1) of Table 2). Relative to the average growth rate in the number of consolidated affiliates of $(=5.47 \%$, cf. Table 1$)$, this corresponds to a reduction of $17 \%$.
} 
branches but also incorporated affiliates. Specifications (4) to (6) add controls for the group's size, productivity and capital intensity. Larger corporate groups (measured in terms of the total capital stock) display a higher growth rate of affiliate numbers. Moreover, specification (5) shows that the larger the group profit the larger is the growth rate in affiliate numbers. In contrast, a high capital intensity is associated with a decline of the number of affiliates. The inclusion of these control characteristics renders the coefficient estimate for the number of consolidated affiliates in 1998 negative and statistically significant suggesting that corporations with a larger number of affiliates grow at a lower rate, ceteris paribus. This might indicate that group level variables such as profits matter relative to the number of firms involved, or it might just reflect a stochastic mean-reversion effect. Specification (7) further controls for differences in the local economic conditions, employing averages of hosting jurisdictions' characteristics. More precisely, we account for the number of inhabitants, the number of employees and the unemployment rate in 1998. Only the coefficient estimate for the average employment variable suggests a marginally significant positive influence on the growth rate of the number of affiliates, the coefficient estimates for the other control variables remain statistically insignificant. At any rate, though, the inclusion of the additional controls do not affect the coefficient estimate for the tax-rate variance, that also remains statistically significant suggesting that an increase in the variance of the tax rate by one standard deviation reduces the growth rate of the number of consolidated affiliates by $22.4 \%$.

In specification (8) we further check whether the coefficient for the variance of the tax rate simply picks up variation of other firm characteristics like size or profitability that may be correlated with the variation of tax rates across affiliates as well as with the growth rate in the group's number of consolidated affiliates. The estimate for the variance in the size of the capital stock thereby suggests that the variance in affiliate size exerts a statistically significant positive effect on the growth rate of the number of consolidated affiliates. This indicates that groups which comprise rather heterogeneous affiliates in terms of size in 1998 are more likely to increase the number of consolidated affiliates. The coefficient estimate for the variance in affiliate profits exhibits a statistically significant negative effect. This might indicate that with a strong 
variation in profitability between affiliates in 1998, the MJE may have an incentive to shut down the relatively unprofitable subsidiaries. However, an alternative explanation, in line with the theoretical model above, is that MJEs with a larger variance in terms of profits that have avoided separate accounting before the reform in order to gain from the possibility of loss offset are now re-organizing. This directly translates into a reduction in the growth rate of affiliate numbers. A similar explanation applies to the negative significant effect of the variation in the affiliates' capital intensity. However, the coefficient estimate for the variation of the tax rates again remains stable and statistically significant. Evaluated at the sample mean, the coefficient estimate suggests that an increase in the tax variance measure by one standard deviation reduces the affiliate growth rate by $22.8 \%$.

So far, our analysis employed the variance of the local business tax-rates across affiliates in order to capture the MJEs' profit shifting opportunities under non-consolidation. To check whether our results are robust against alternative measures of the tax rate distribution, we re-estimate the specifications in Table 2 employing the ratio of the 90th over the 10th percentile of a group's tax rate distribution. The larger this tax measure, the higher is the variation in the tax rate distribution within the corporate group in 1998 and the lower the growth rate in the number of affiliates should be. This presumption is strongly confirmed by the estimation results presented in Table 3. The coefficient estimate for the measure of the tax-rate dispersion is negative and statistically significant at the $1 \%$ level suggesting that an increase in this indicator by one standard deviation reduces the growth rate of the number of consolidated affiliates by $15.0 \%$. Specifications (2) to (8) show that this result is robust against the inclusion of the control variables employed above which also carry the above detected signs. The coefficient estimate in specification (8) indicates that an increase in the tax-rate dispersion measure by one standard deviation reduces the growth rate of affiliate numbers by $20.7 \% .^{10}$ Thus, the estimated effect is quantitatively close to the effect found on the basis of the tax variance measure.

\footnotetext{
${ }^{10}$ Note that the dispersion measures for affiliate characteristics (e.g. capital stock and profit levels) which are included in specification (8), are calculated as the ratio of the 90th percentile of the intragroup distribution over the 10th percentile of the intra-group distribution to be consistent with the calculation of the measure of the tax-rate variation.
} 
As pointed out in Section 4, the empirical distribution of the relative change in the number of consolidated affiliates between 1998 and 2001 suggests that a limited dependent variable model might be a reasonable alternative to OLS. We, therefore, also provide results based on an ordered probit model that is concerned with three values of the dependent variable: 'affiliate number decreased' $(=1)$, 'affiliate number stayed constant' $(=2)$ and 'affiliate number increased' $(=3)$.

The local business tax-rate variation across group affiliates is captured by the ratio of the 90th over the 10th percentile of the tax distribution (employing the local business tax variance leads to comparable results). The results are presented in Table 4. Specifications (1) to (8) resemble the estimations presented in Tables 2 and 3. We again find the same picture in the sense that the dispersion measure exerts a statistically significant negative impact on the change in affiliate numbers. The control variables also show the same signs as above. In a second step, we additionally experiment with alternative categorizations of the dependent variable (e.g. the use of five categories) and found that the results prove robust against alternative specifications. ${ }^{11}$

We conclude from our empirical analysis that the evidence supports our theoretical prediction. MJEs experiencing a large variation in the tax rate distribution among affiliates are found to have reduced the number of consolidated affiliates compared with MJEs with a low variation of tax rates across affiliates. This corresponds to the view that the former groups can generate larger profit shifting gains under nonconsolidation and thus reduce their affiliate numbers more strongly in response to the legal change in German tax law in 2001.

\section{Conclusion}

While separate-accounting (SA) rules govern the taxation of multinational enterprises in the current system of international taxation, these rule are often criticized since they give rise to profit-shifting opportunities. As an alternative, a system of profit

\footnotetext{
${ }^{11}$ The results of these estimations are available from the authors upon request.
} 
consolidation combined with some formulary apportionment (FA) has been suggested in the literature emphasizing that group-wide consolidation would abolish profit-shifting incentives. However, our paper shows that profit-shifting incentives remain important under FA. We argue that a particular problem faced by FA is that profit shifting within the corporate group is only abolished if all group affiliates of a multijurisidictional enterprise (MJE) are consolidated. Since the rules that determine the consolidated group usually rest on the degree of economic and financial integration which ultimately reflect firm decisions, MJE will experience some leeway in deciding whether affiliates are included in the basis of consolidation. As a consequence, consolidation becomes a strategic tool for an MJE's tax planning.

To analyze strategic consolidation we develop a theoretical model of an MJE that runs affiliates in different jurisdictions and that decides about whether or not to consolidate these affiliates. By comparing the maximized after-tax profit under the two alternatives, we identify a basic trade-off determining the consolidation decision. On the one hand, we note that exclusion of affiliates is associated with costs, notably, loss offset opportunities cannot be exploited. On the other hand, non-consolidation has the benefit of maintaining profit-shifting opportunities. This benefit, and thus the incentive for non-consolidation, turns out to be the more important the larger the dispersion of statutory tax rates within the whole corporate group.

The empirical analysis provides evidence that MJEs which are taxed according to FA regulations do, in fact, strategically exclude affiliates from consolidation. The analysis uses a unique firm-level data set that comprises confidential tax-return data for the whole population of German firms in 1998 and 2001. To identify the strategic consolidation decision, we make use of an exogeneous variation in the German tax law which came into effect in January 2001 and reduced the costs of excluding affiliates from the basis of consolidation under the German local business tax system.

Our estimation results confirm the theoretical prediction and suggest that an increase in the variation of tax rates within a corporate group by one standard deviation reduces the growth rate of the number of consolidated affiliates by around $20 \%$. This finding is stable for a large set of specifications and robustness checks. 
The paper thus indicates that MJEs tend to strategically exclude affiliates from consolidation under FA to preserve profit shifting opportunities within the multi-jurisdictional group. However, if profit shifting channels to unconsolidated group affiliates remain open, this may - at least to some extent - undermine the effectiveness of the FA system in abolishing profit shifting activities. Thus, as a direct policy implication our paper suggests that the design of FA regimes should attach large costs to excluding affiliates from the basis of consolidation. Otherwise MJEs tend to leave affiliates in low-tax jurisdictions un-consolidated and engage in profit shifting activities despite the existence of a FA regime. Again, the German case offers some example. After a series of reforms that have relaxed the rules for consolidation, starting with the reform that the above analysis has addressed, tax authorities faced increasing problems to suppress profitshifting at the subnational level, despite the implementation of FA. In 2004, then, the federal legislator in Germany took resort to defining a minimum tax rate for the local business tax.

\section{References}

Anand, B. N., and R. Sansing (2000), The weighting game: formula apportionment as an instrument of public policy. National Tax Journal 53, 183-199.

Bucovetsky, S. and A. Haufler, A. (2008), 'Tax competition when firms choose their organizational form: should tax loopholes for multinational be closed?', Journal of International Economics $74,188-201$.

Buettner, T. (2003), 'Tax Base Effects and Fiscal Externalities of Local Capital Taxation: Evidence from a Panel of German Jurisdictions', Journal of Urban Economics 54, 110-128.

Desai, M. A., C. F. Foley and J. R. Hines Jr. (2004), 'The Costs of Shared Ownership: Evidence From International Joint Ventures', Journal of Financial Economics 73, 323-374.

Devereux, M. P. (2006), 'The Impact of Taxation on the Location of Capital, Firms and Profit: A Survey of Empirical Evidence', mimeo.

Devereux, M. P. and S. Loretz (2008), 'The Effects of EU Formula Apportionment on Corporate Tax Revenues' Fiscal Studies, 29, 1-33.

Eggert, W. and G. Schjelderup (2003), 'Symmetric Tax Competition under Formula Apportionment', Journal of Public Economic Theory 5, 439-46. 
Eichner, T. and M. Runkel (2008), Why the European Union Should Adopt Formula Apportionment with a Sales Factor, Scandinavian Journal of Economics, forthcoming.

Fuest, C. (2008), 'The European Commission's proposal for a Common Consolidated Corporate Tax Base', mimeo.

Fuest, C., Hemmelgarn, T. and F. Ramb (2007), 'How Would the Introduction of an EU-wide Formula Apportionment Affect the Size and the Distribution of the Corporate Tax Base? An Analysis Based on German Multinationals', International Tax and Public Finance 14(5), 605626.

Goolsbee, A. and E. L. Maydew (2000), 'Coveting thy Neighbor's Manufacturing: The dilemma of state income apportionment', Journal of Public Economics 75, 125-143.

Gordon, R. and J. D. Wilson (1986), 'An Examination of Multijurisdictional Corporate Income Taxation under Formula Apportionment', Econometrica 54, 1357-1373.

Herzig, N. (2003), Einfuehrung, in: Herzig, N. (ed.), Organschaft, Stuttgart, 1-35.

Huizinga, H. and J. Voget (2006), 'International Taxation and the Direction and Volume of CrossBorder M\&As', CEPR Discussion Paper No. 5974.

Kind, J. K., K. H. Midelfart and G. Schjelderup(2005), 'Corporate Tax Systems, Multinational Entreprises, and Economic Integration', Journal of International Economics 65, 507-521.

Kirsch, M. and F. Grube (2001), 'Die Organschaft nach dem Steuersenkungsgesetz - fuer die Gewerbesteuer noch keine wirkliche Vereinfachung', GmbHR - GmbH-Rundschau 9, 371-375.

McLure, C.E. (1980), 'The State Corporate Income Tax: Lambs in Wolves' Clothing', in: Aaron, A.J. and M.J. Boskin (Eds.), The Economics of Taxation, Washington DC: The Brookings Institution, 327-336.

Mintz, J. (1999), 'Globalization of the Corporate Income Tax: The Role of Allocation', Finanzarchiv, $56,389-423$.

Mintz, J. and M. Smart (2004), 'Income Shifting, Investment, and Tax Competition: Theory and Evidence from Provincial Taxation in Canada', Journal of Public Economics 88, 1149-1168.

Nielsen, S. B., P. Raimondos-M?ller and G. Schjelderup (2006), 'Tax Spillovers under Separate Accounting and Formula Apportionment', mimeo.

Pethig, R. and A. Wagener (2008), 'Profit Tax Competition and Formula Apportionment', International Tax and Public Finance, forthcoming.

Pinto, S.M. (2007), 'Corporate Profit Tax, Capital Mobility, and Formula Apportionment', Journal of Urban Economics 62, 76-102.

Raedler, A. (2003), Ueberlegungen zur Gewerbesteuer, ifo Schnelldienst, 9 (2003), 14-19.

Riedel, N. and M. Runkel (2007), 'Company Tax Reform with a Water's Edge', Journal of Public Economics 91, 1533-1554. 
Riedel, N. (2008), 'The Downside of Formula Apportionment: Evidence on Factor Demand Distortions', mimeo.

Sørensen, P.B. (2004), 'Company Tax Reform in the European Union', International Tax and Public Finance 11, 91-115.

Weichenrieder, A. and J. Mintz (2008), 'What Determines the Use of Holding Companies and Ownership Chains?', Oxford University Centre for Business Taxation Working Paper No. 08/03.

Weiner, J. (2006), Company Tax Reform in the European Union: Guidance from the United States and Canada on Implementing Formulary Apportionment in the EU, New York.

Wellisch, D. (2004), 'Taxation under Formula Apportionment - Tax Competition, Tax Incidence, and the Choice of Apportionment Factors', Finanzarchiv 60, 24-41.

Weltzer, J. W. (1995), 'Should the US adopt formula apportionment', National Tax Journal 48, 357-362. 


\begin{tabular}{|c|c|c|}
\hline Variable & Mean & Standard Deviation \\
\hline \multicolumn{3}{|l|}{ Affiliate Numbers } \\
\hline Difference Number of Affiliates 2001-1998 & 0.1077 & 11.3994 \\
\hline Growth Rate Number of Affiliates 2001-1998 & 0.0547 & 0.6298 \\
\hline Number of Affiliates 1998 & 4.1330 & 49.2584 \\
\hline \multicolumn{3}{|l|}{ Measures of Tax-Rate Variation } \\
\hline Tax Variance 1998 (in Local Business Tax Points) & 950.3482 & 1631.7570 \\
\hline $90^{t h} / 10^{t h}$ Percentile, Tax Rate & 1.1534 & 0.1627 \\
\hline \multicolumn{3}{|l|}{ Other Jurisdictional Characteristics } \\
\hline Inhabitants 1998 & $104,423.8$ & $152,840.5$ \\
\hline Employment 1998 & $48,516.4$ & $78,396.7$ \\
\hline Unemployment Rate 1998 & 0.1295 & 0.0456 \\
\hline \multicolumn{3}{|l|}{ Group Characteristics } \\
\hline Capital 1998 (in 1,000 $\mathrm{DM}^{*}$ ) & $8,363.0$ & $414,000.0$ \\
\hline Pre-tax Profit 1998 (in 1,000 DM*) & 56.5 & $1,791.9$ \\
\hline Capital Intensity 1998 & 657.5 & $84,672.4$ \\
\hline $90^{t h} / 10^{t h}$ Percentile, Capital 1998 & 1140.0 & $110,603.4$ \\
\hline $90^{t h} / 10^{t h}$ Percentile, Pre-tax Profit 1998 & 37.7 & 709.7 \\
\hline $90^{t h} / 10^{t h}$ Percentile, Relative Wages 1998 & 2617.2 & $277,360.5$ \\
\hline $90^{t h} / 10^{t h}$ Percentile, Capital Intensity 1998 & 591.2 & $175,942.9$ \\
\hline
\end{tabular}

* DM is the abbreviation for 'Deutsche Mark', i.e. the German currency prior to the introduction of the Euro. The exchange rate Deutsche Mark to Euro is approximately 2:1. 


\begin{tabular}{|c|c|c|c|c|c|c|c|c|c|c|c|}
\hline \multirow{9}{*}{ 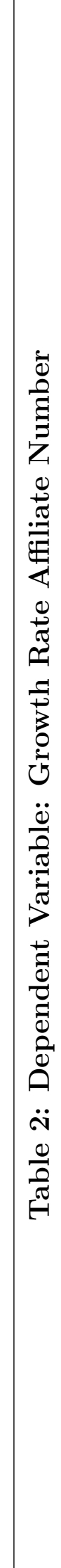 } & (क) & 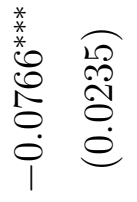 & 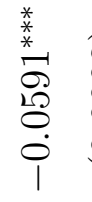 & $\begin{array}{l}\text { बิ } \\
\dot{8} \\
\dot{e}\end{array}$ & $\begin{array}{lc}2 & \widehat{F} \\
0 & 0 \\
0 & 0 \\
0 & 0 \\
0 & 0\end{array}$ & 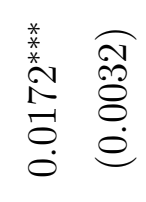 & 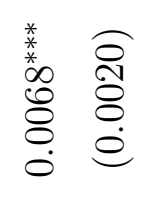 & 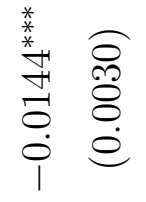 & 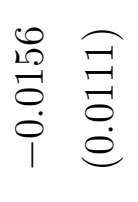 & 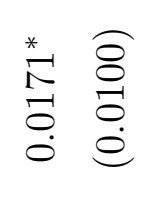 & $\begin{array}{ll}\text { I } & 0 \\
0 & 8 \\
0 & \stackrel{0}{0} \\
0 & 0 \\
1 & \varrho\end{array}$ \\
\hline & $\Sigma$ & 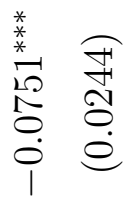 & 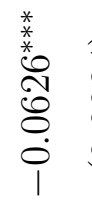 & $\begin{array}{l}\stackrel{\overbrace{}}{\infty} \\
\stackrel{\infty}{0} \\
\stackrel{0}{0}\end{array}$ & 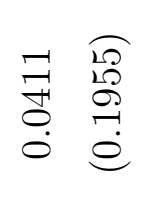 & 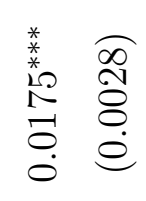 & 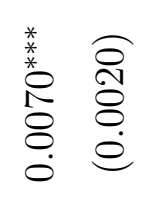 & 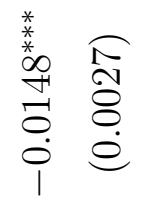 & 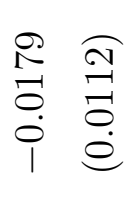 & 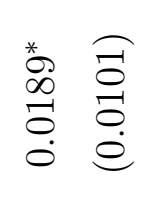 & 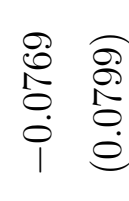 \\
\hline & (e) & 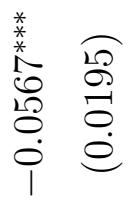 & $\begin{array}{l}\stackrel{*}{*} \\
\stackrel{*}{*} \\
\stackrel{0}{0} \\
\stackrel{0}{0} \\
1\end{array}$ & $\begin{array}{l}\widehat{D} \\
0 \\
0 \\
0 \\
\dot{e}\end{array}$ & 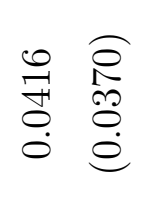 & 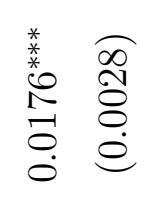 & 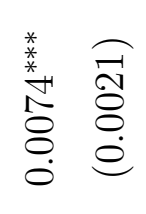 & 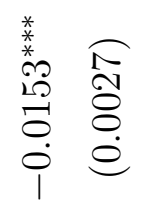 & & & \\
\hline & (2) & 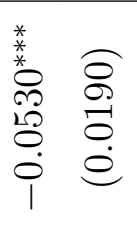 & $\begin{array}{l}\stackrel{*}{*} \\
\stackrel{+}{*} \\
\stackrel{2}{0} \\
\stackrel{0}{0} \\
1\end{array}$ & $\begin{array}{l}\widehat{P} \\
\stackrel{0}{8} \\
\dot{e}\end{array}$ & 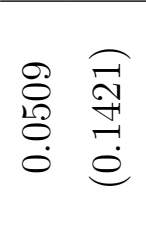 & $\begin{array}{ll}* & 0 \\
* & 0 \\
0 & 0 \\
0 & 8 \\
0 & 0 \\
0 & 0\end{array}$ & 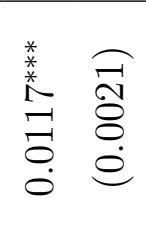 & & & & \\
\hline & $\nexists$ & \begin{tabular}{ll}
$\stackrel{*}{*}$ & $\widehat{6}$ \\
\multirow{2}{*}{} & $\overrightarrow{0}$ \\
$\stackrel{1}{0}$ & 0 \\
0 & 0 \\
0 & 0 \\
1 & 0
\end{tabular} & $\begin{array}{l}\frac{*}{*} \\
\stackrel{*}{*} \\
8 \\
0 \\
0 \\
1\end{array}$ & $\begin{array}{l}\overparen{\vec{\Xi}} \\
\dot{\Xi} \\
\dot{e}\end{array}$ & $\begin{array}{ll}\stackrel{*}{*} & \widehat{O} \\
0 & \stackrel{1}{0} \\
0 & \stackrel{0}{0} \\
0 & 0 \\
0 & 0\end{array}$ & 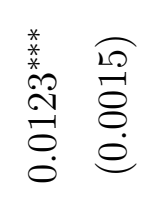 & & & & & \\
\hline & (2) & 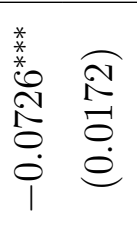 & $\begin{array}{l}\stackrel{2}{0} \\
\stackrel{0}{0} \\
\dot{0} \\
\dot{1}\end{array}$ & $\begin{array}{l}\widehat{\approx} \\
\stackrel{8}{8} \\
\stackrel{0}{e}\end{array}$ & 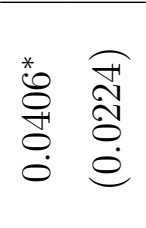 & & & & & & \\
\hline & ब( & 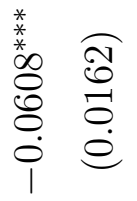 & $\begin{array}{l}m \\
\ddot{8} \\
\dot{0} \\
\dot{0}\end{array}$ & $\begin{array}{l}\text { तิ } \\
\stackrel{\Xi}{0} \\
\stackrel{e}{e}\end{array}$ & & & & & & & \\
\hline & $\approx$ & 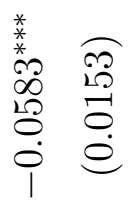 & $\begin{array}{l}\infty \\
\tilde{8} \\
\dot{0} \\
\dot{1}\end{array}$ & $\begin{array}{l}\text { đิ } \\
\stackrel{8}{0} \\
\dot{e}\end{array}$ & & & & & & & \\
\hline & 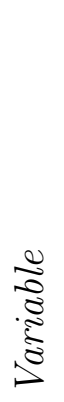 & 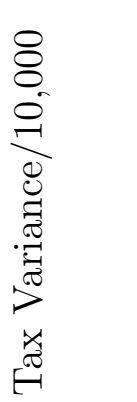 & 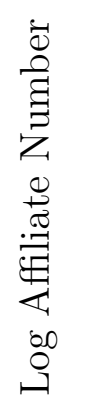 & & 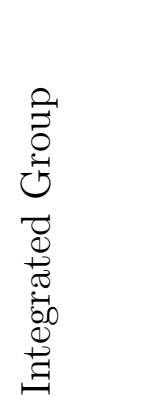 & 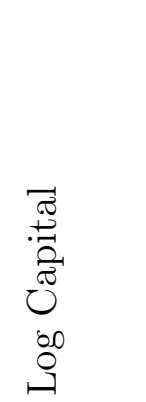 & $\begin{array}{l}\overrightarrow{0} \\
0 \\
0 \\
0 \\
0 \\
\tilde{c} \\
0 \\
0 \\
0 \\
0.0 \\
0 \\
0\end{array}$ & 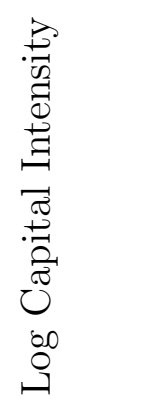 & 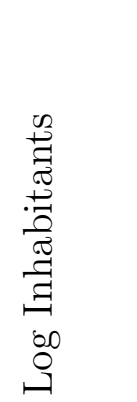 & 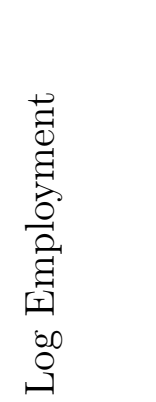 & 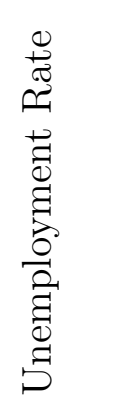 \\
\hline
\end{tabular}




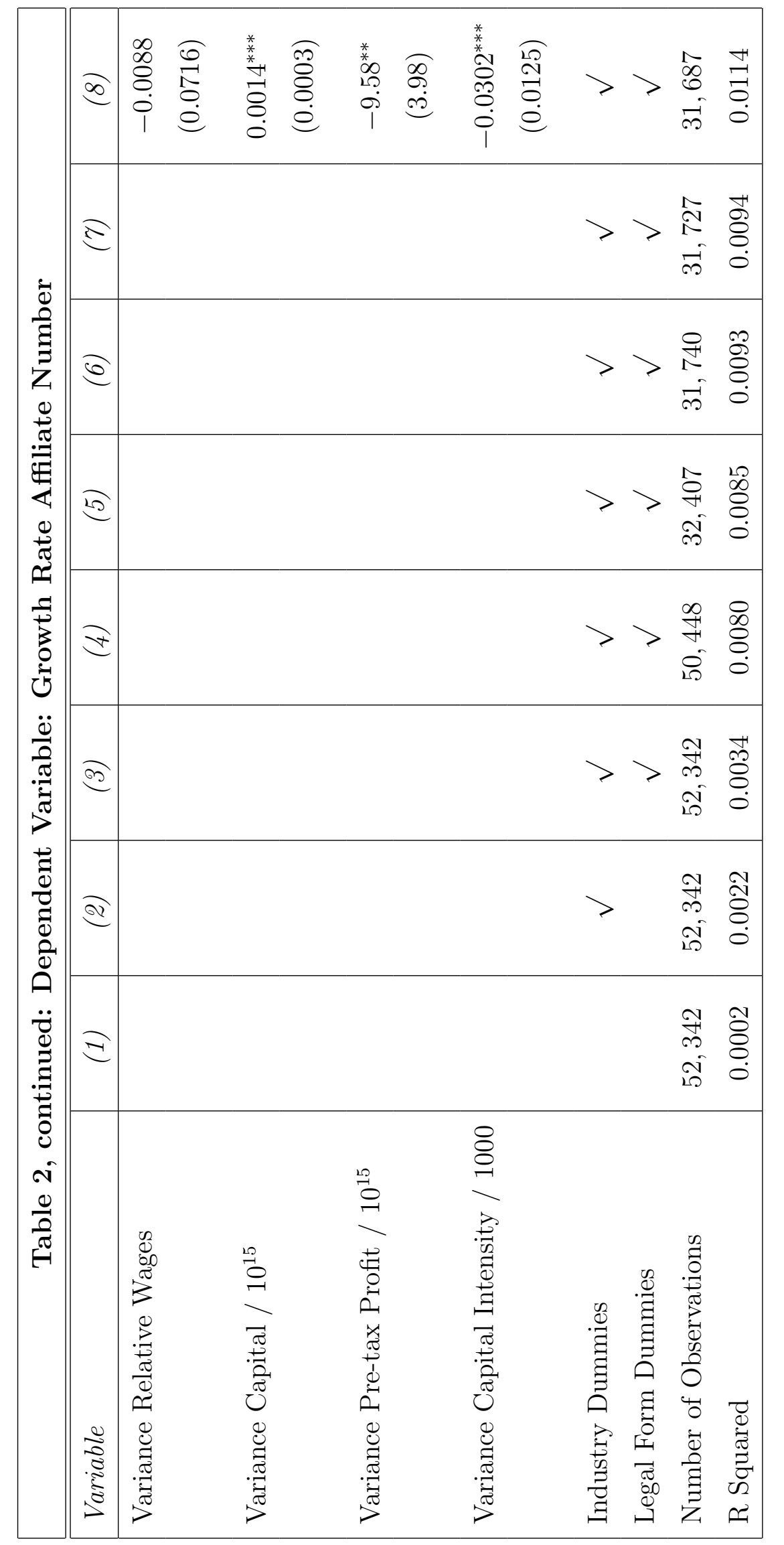

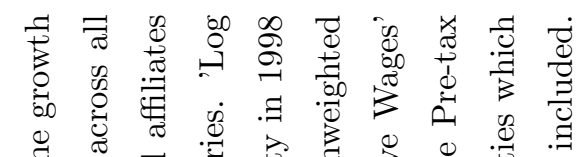

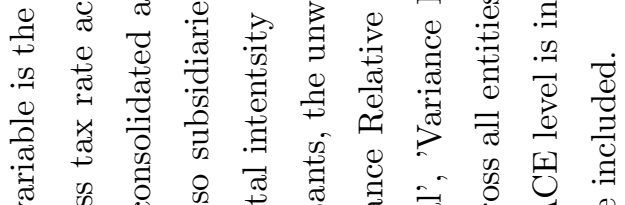
蛋 $\begin{gathered}0 \\ 0\end{gathered}$

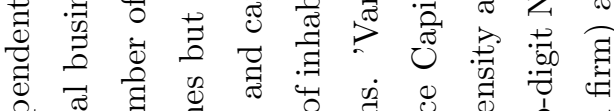
茕

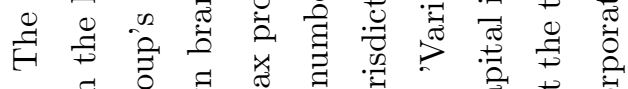

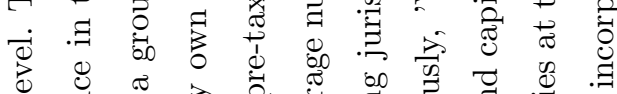

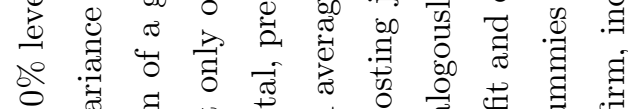

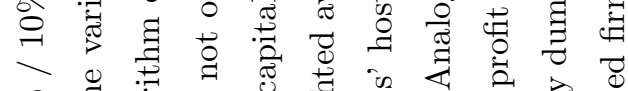

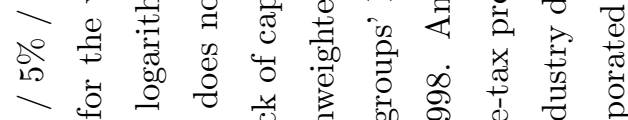

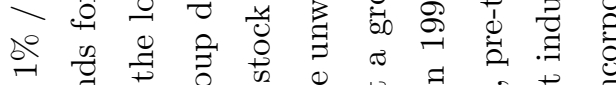

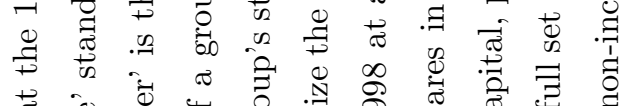
๘ 苛

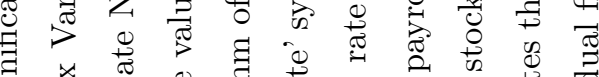

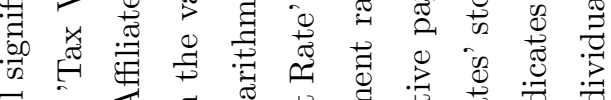

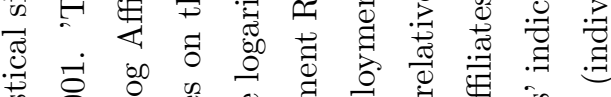
泀

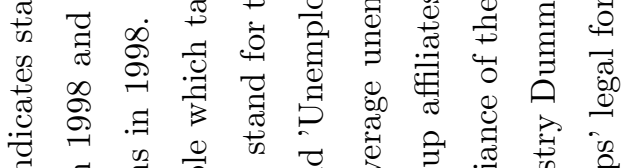

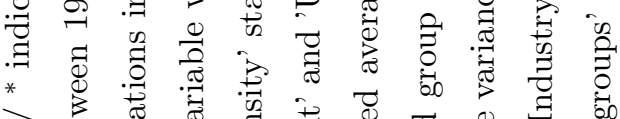
*

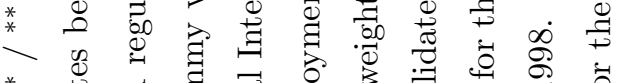

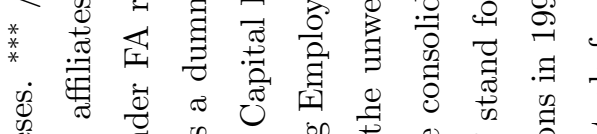

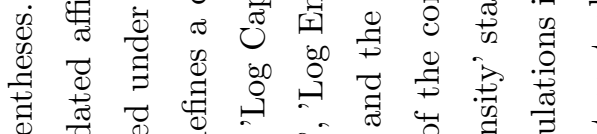

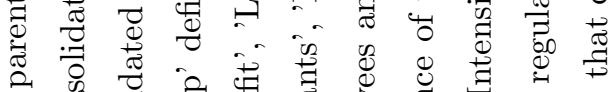

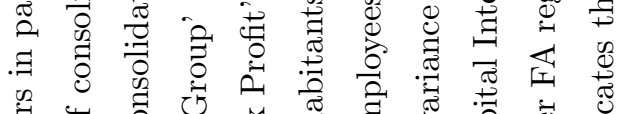
范

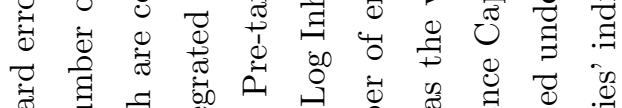

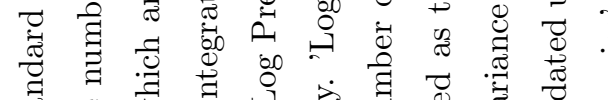
要专

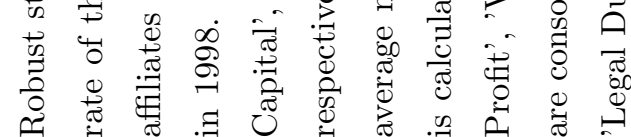




\begin{tabular}{|c|c|c|c|c|c|c|c|c|c|c|}
\hline \multirow{9}{*}{ 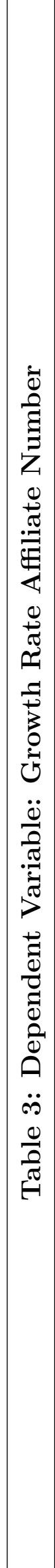 } & (2) & 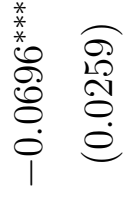 & 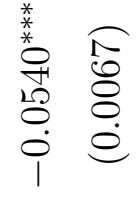 & 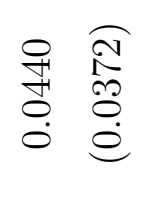 & 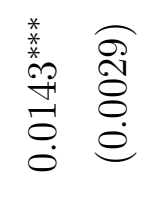 & 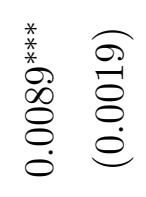 & 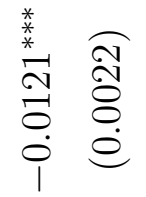 & 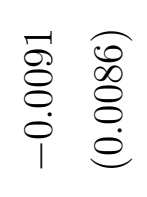 & 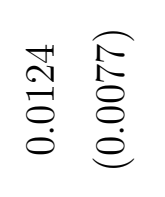 & 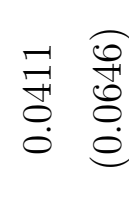 \\
\hline & $\Sigma$ & 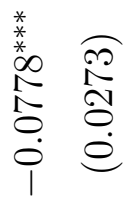 & $\begin{array}{ll}\stackrel{*}{*} & \widehat{\Omega} \\
\infty & \mathbb{2} \\
0 & 8 \\
0 & 8 \\
0 & 0 \\
0 & 0\end{array}$ & 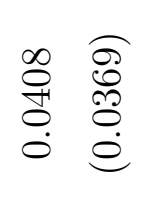 & 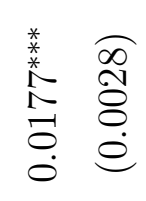 & 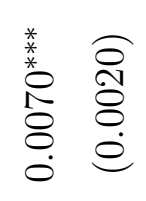 & 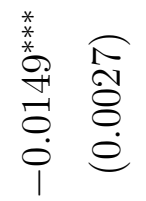 & 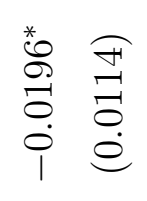 & 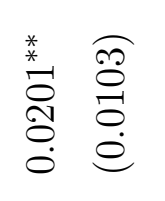 & 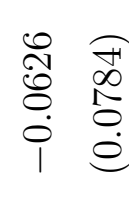 \\
\hline & e & 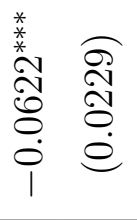 & \begin{tabular}{ll}
$\frac{*}{*}$ & \multicolumn{1}{c}{} \\
0 & 0 \\
0 & $\infty$ \\
0 & 8 \\
0 & 0 \\
0 & 0 \\
1 & 0
\end{tabular} & 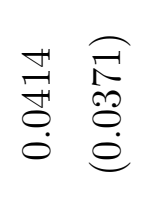 & 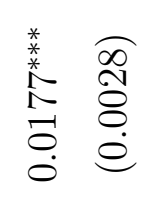 & 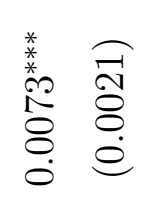 & 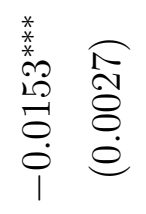 & & & \\
\hline & $\sqrt{20}$ & 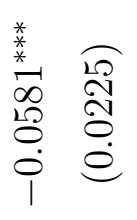 & 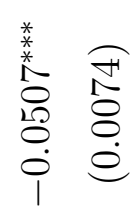 & 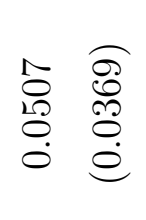 & $\begin{array}{ll}* & 0 \\
* & 0 \\
0 & 0 \\
8 & 0 \\
0 & 0 \\
0 & 0\end{array}$ & 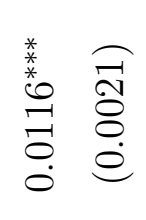 & & & & \\
\hline & $\nexists$ & 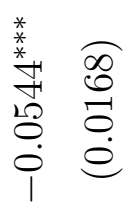 & 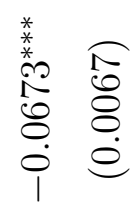 & $\begin{array}{ll}\stackrel{*}{*} & \widehat{O} \\
0 & \stackrel{0}{0} \\
0 & \stackrel{0}{0} \\
0 & 0 \\
0 & 0\end{array}$ & 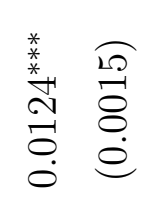 & & & & & \\
\hline & (2) & 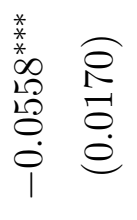 & 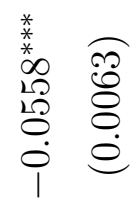 & 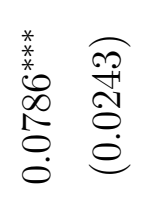 & & & & & & \\
\hline & શ & 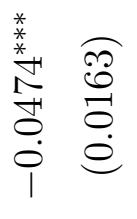 & 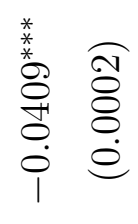 & & & & & & & \\
\hline & $\approx$ & 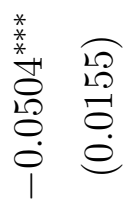 & 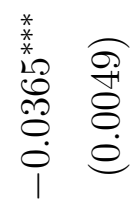 & & & & & & & \\
\hline & 胥 & 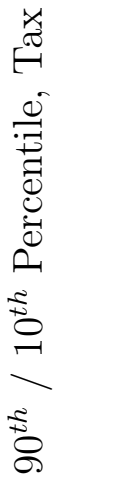 & 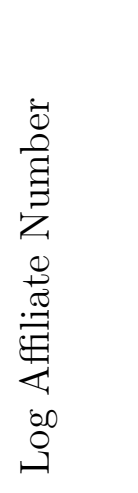 & 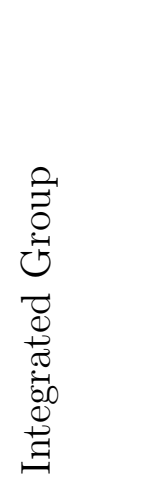 & 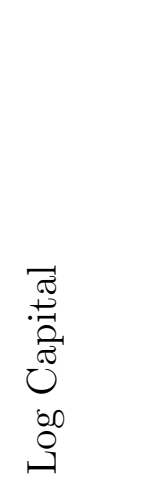 & 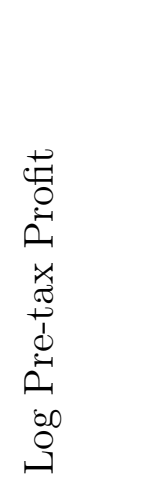 & 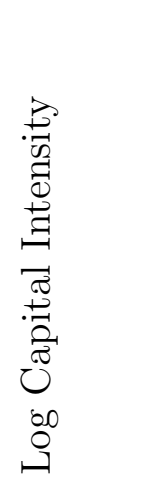 & 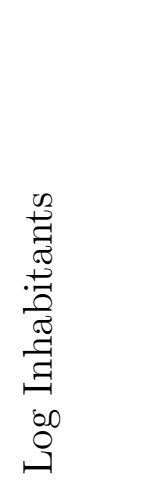 & 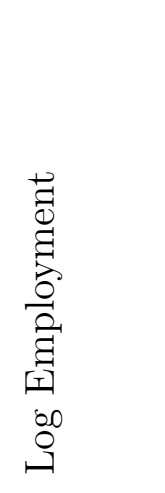 & 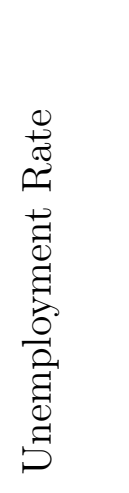 \\
\hline
\end{tabular}




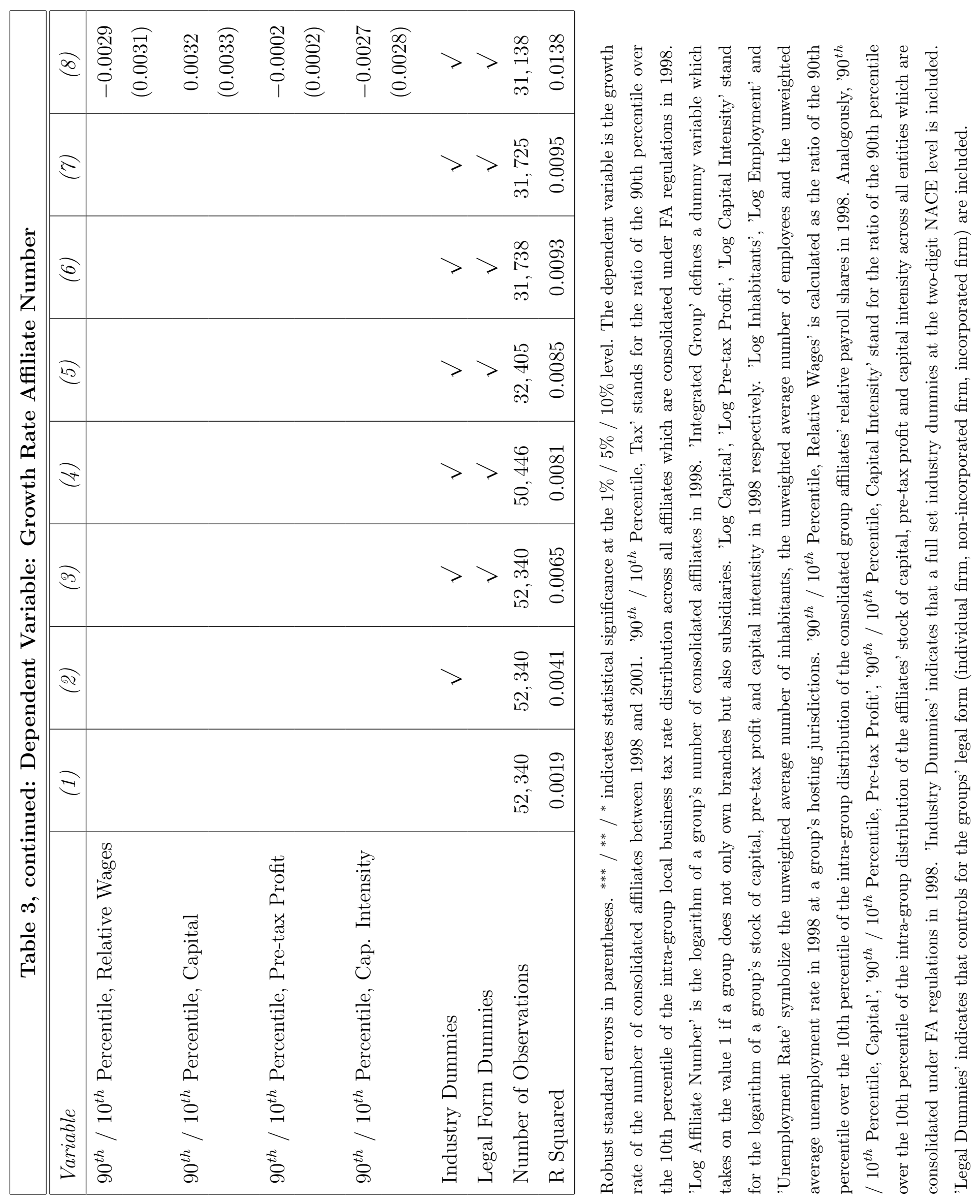




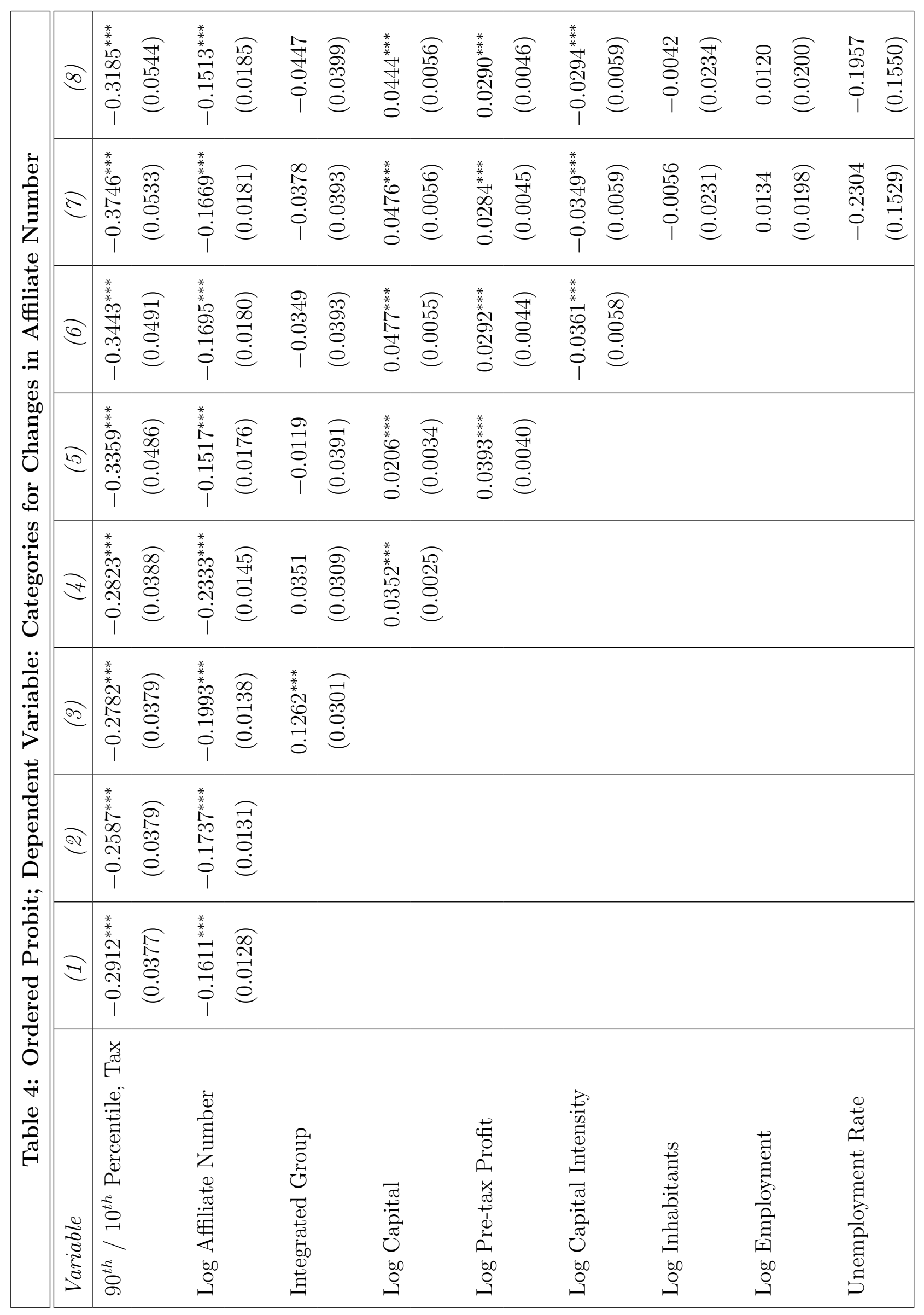




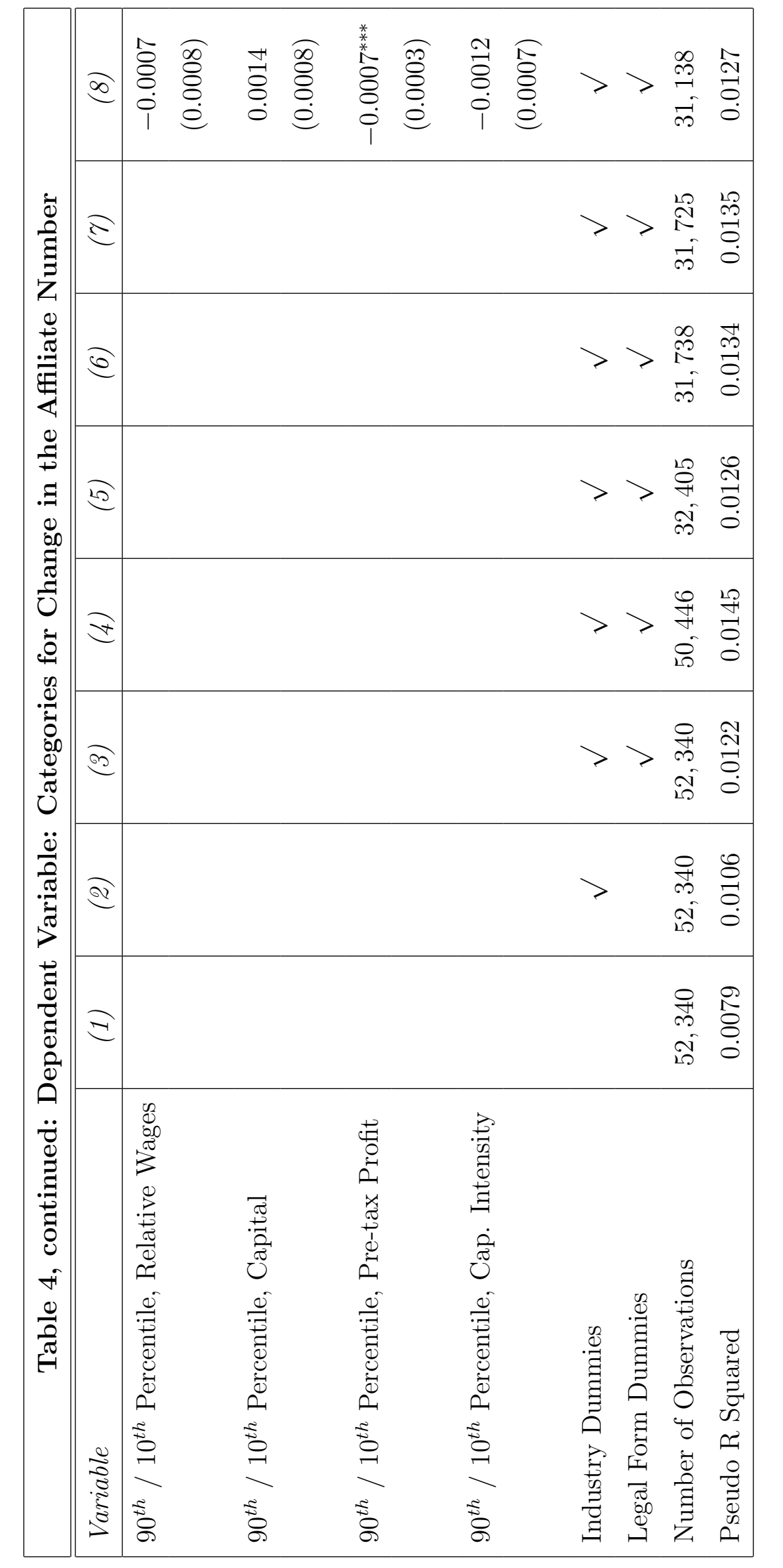

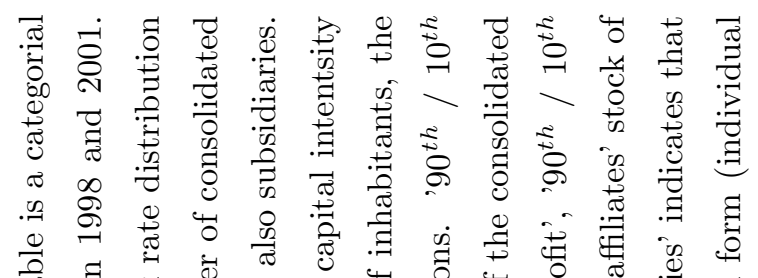

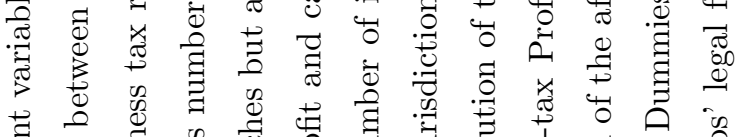

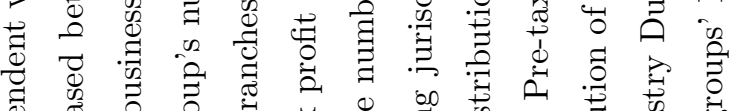

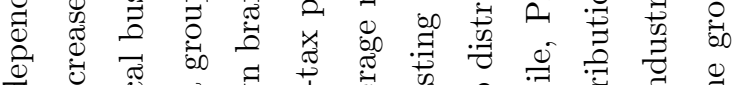

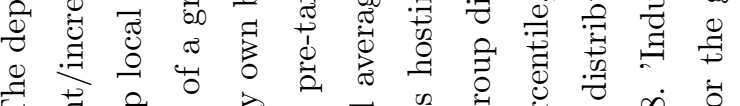

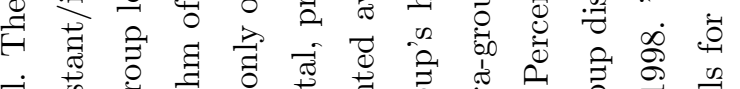
बं

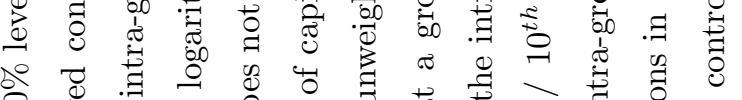

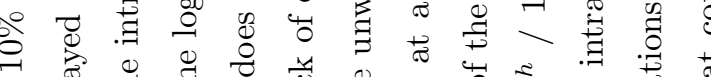

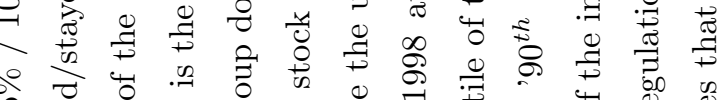
过

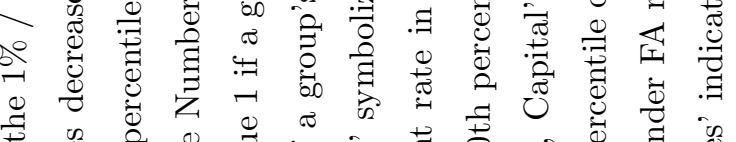

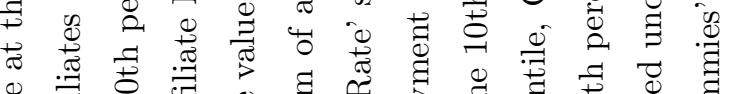

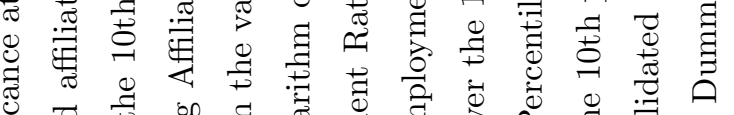

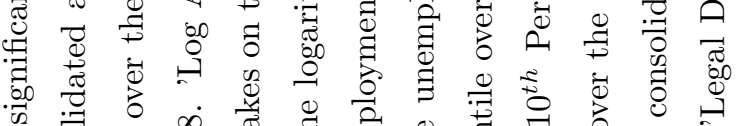

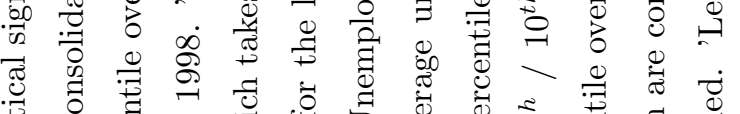
葡

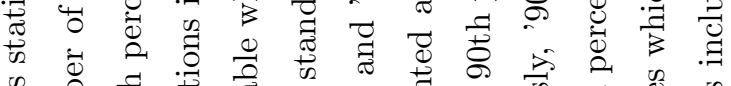

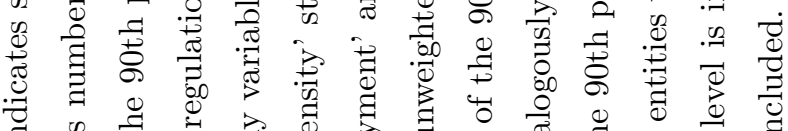

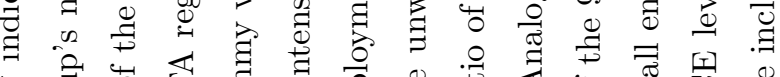

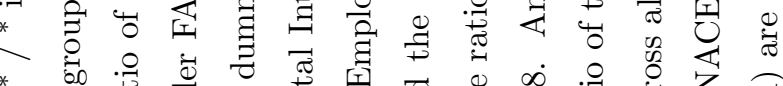

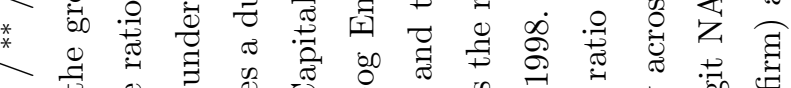
* 山ें

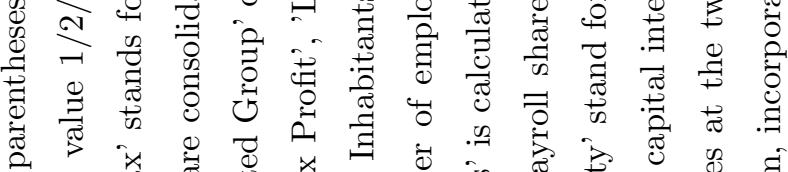
.

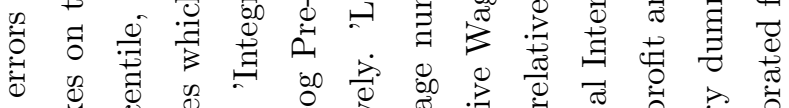

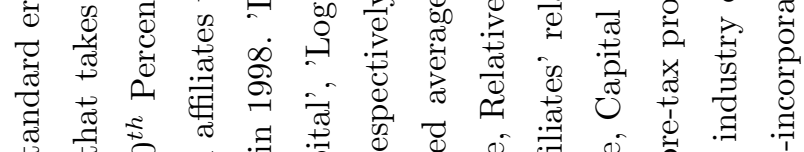

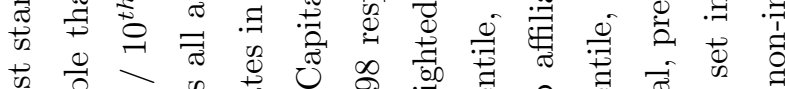

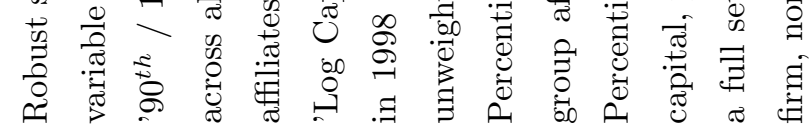




\section{CESifo Working Paper Series}

for full list see www.cesifo-group.org/wp

(address: Poschingerstr. 5, 81679 Munich, Germany, office@cesifo.de)

2421 Kamila Fialová and Ondřej Schneider, Labour Market Institutions and their Effect on Labour Market Performance in the New EU Member Countries, October 2008

2422 Alexander Ludwig and Michael Reiter, Sharing Demographic Risk - Who is Afraid of the Baby Bust?, October 2008

2423 Doina Maria Radulescu and Michael Stimmelmayr, The Welfare Loss from Differential Taxation of Sectors in Germany, October 2008

2424 Nikolaus Wolf, Was Germany ever United? Evidence from Intra- and International Trade 1885 - 1933, October 2008

2425 Bruno S. Frey, David A. Savage and Benno Torgler, Noblesse Oblige? Determinants of Survival in a Life and Death Situation, October 2008

2426 Giovanni Facchini, Peri Silva and Gerald Willmann, The Customs Union Issue: Why do we Observe so few of them?, October 2008

2427 Wido Geis, Silke Uebelmesser and Martin Werding, Why go to France or Germany, if you could as well go to the UK or the US? Selective Features of Immigration to four major OECD Countries, October 2008

2428 Geeta Kingdon and Francis Teal, Teacher Unions, Teacher Pay and Student Performance in India: A Pupil Fixed Effects Approach, October 2008

2429 Andreas Haufler and Marco Runkel, Firms' Financial Choices and Thin Capitalization Rules under Corporate Tax Competition, October 2008

2430 Matz Dahlberg, Heléne Lundqvist and Eva Mörk, Intergovernmental Grants and Bureaucratic Power, October 2008

2431 Alfons J. Weichenrieder and Tina Klautke, Taxes and the Efficiency Costs of Capital Distortions, October 2008

2432 Andreas Knabe and Ronnie Schöb, Minimum Wage Incidence: The Case for Germany, October 2008

2433 Kurt R. Brekke and Odd Rune Straume, Pharmaceutical Patents: Incentives for R\&D or Marketing?, October 2008

2434 Scott Alan Carson, Geography, Insolation, and Institutional Change in $19^{\text {th }}$ Century African-American and White Stature in Southern States, October 2008

2435 Emilia Del Bono and Daniela Vuri, Job Mobility and the Gender Wage Gap in Italy, October 2008 
2436 Marco Angrisani, Antonio Guarino, Steffen Huck and Nathan Larson, No-Trade in the Laboratory, October 2008

2437 Josse Delfgaauw and Robert Dur, Managerial Talent, Motivation, and Self-Selection into Public Management, October 2008

2438 Christian Bauer and Wolfgang Buchholz, How Changing Prudence and Risk Aversion Affect Optimal Saving, October 2008

2439 Erich Battistin, Clara Graziano and Bruno Parigi, Connections and Performance in Bankers' Turnover: Better Wed over the Mixen than over the Moor, October 2008

2440 Erkki Koskela and Panu Poutvaara, Flexible Outsourcing and the Impacts of Labour Taxation in European Welfare States, October 2008

2441 Marcelo Resende, Concentration and Market Size: Lower Bound Estimates for the Brazilian Industry, October 2008

2442 Giandomenico Piluso and Roberto Ricciuti, Fiscal Policy and the Banking System in Italy. Have Taxes, Public Spending and Banks been Procyclical in the Long-Run? October 2008

2443 Bruno S. Frey and Katja Rost, Do Rankings Reflect Research Quality?, October 2008

2444 Guglielmo Maria Caporale, Antoaneta Serguieva and Hao Wu, Financial Contagion: Evolutionary Optimisation of a Multinational Agent-Based Model, October 2008

2445 Valentina Bosetti, Carlo Carraro and Massimo Tavoni, Delayed Participation of Developing Countries to Climate Agreements: Should Action in the EU and US be Postponed?, October 2008

2446 Alexander Kovalenkov and Xavier Vives, Competitive Rational Expectations Equilibria without Apology, November 2008

2447 Thiess Buettner and Fédéric Holm-Hadulla, Cities in Fiscal Equalization, November 2008

2448 Harry H. Kelejian and Ingmar R. Prucha, Specification and Estimation of Spatial Autoregressive Models with Autoregressive and Heteroskedastic Disturbances, November 2008

2449 Jan Bouckaert, Hans Degryse and Thomas Provoost, Enhancing Market Power by Reducing Switching Costs, November 2008

2450 Frank Heinemann, Escaping from a Combination of Liquidity Trap and Credit Crunch, November 2008

2451 Dan Anderberg, Optimal Policy and the Risk Properties of Human Capital Reconsidered, November 2008 
2452 Christian Keuschnigg and Evelyn Ribi, Outsourcing, Unemployment and Welfare Policy, November 2008

2453 Bernd Theilen, Market Competition and Lower Tier Incentives, November 2008

2454 Ondřej Schneider, Voting in the European Union - Central Europe's Lost Voice, November 2008

2455 Oliver Lorz and Gerald Willmann, Enlargement versus Deepening: The Trade-off Facing Economic Unions, November 2008

2456 Alfons J. Weichenrieder and Helen Windischbauer, Thin-Capitalization Rules and Company Responses, Experience from German Legislation, November 2008

2457 Andreas Knabe and Steffen Rätzel, Scarring or Scaring? The Psychological Impact of Past Unemployment and Future Unemployment Risk, November 2008

2458 John Whalley and Sean Walsh, Bringing the Copenhagen Global Climate Change Negotiations to Conclusion, November 2008

2459 Daniel Mejía, The War on Illegal Drugs in Producer and Consumer Countries: A Simple Analytical Framework, November 2008

2460 Carola Frydman, Learning from the Past: Trends in Executive Compensation over the Twentieth Century, November 2008

2461 Wolfgang Ochel, The Political Economy of Two-tier Reforms of Employment Protection in Europe, November 2008

2462 Peter Egger and Doina Maria Radulescu, The Influence of Labor Taxes on the Migration of Skilled Workers, November 2008

2463 Oliver Falck, Stephan Heblich and Stefan Kipar, The Extension of Clusters: Differencein-Differences Evidence from the Bavarian State-Wide Cluster Policy, November 2008

2464 Lei Yang and Keith E. Maskus, Intellectual Property Rights, Technology Transfer and Exports in Developing Countries, November 2008

2465 Claudia M. Buch, The Great Risk Shift? Income Volatility in an International Perspective, November 2008

2466 Walter H. Fisher and Ben J. Heijdra, Growth and the Ageing Joneses, November 2008

2467 Louis Eeckhoudt, Harris Schlesinger and Ilia Tsetlin, Apportioning of Risks via Stochastic Dominance, November 2008

2468 Elin Halvorsen and Thor O. Thoresen, Parents' Desire to Make Equal Inter Vivos Transfers, November 2008 
2469 Anna Montén and Marcel Thum, Ageing Municipalities, Gerontocracy and Fiscal Competition, November 2008

2470 Volker Meier and Matthias Wrede, Reducing the Excess Burden of Subsidizing the Stork: Joint Taxation, Individual Taxation, and Family Splitting, November 2008

2471 Gunther Schnabl and Christina Ziegler, Exchange Rate Regime and Wage Determination in Central and Eastern Europe, November 2008

2472 Kjell Erik Lommerud and Odd Rune Straume, Employment Protection versus Flexicurity: On Technology Adoption in Unionised Firms, November 2008

2473 Lukas Menkhoff, High-Frequency Analysis of Foreign Exchange Interventions: What do we learn?, November 2008

2474 Steven Poelhekke and Frederick van der Ploeg, Growth, Foreign Direct Investment and Urban Concentrations: Unbundling Spatial Lags, November 2008

2475 Helge Berger and Volker Nitsch, Gotcha! A Profile of Smuggling in International Trade, November 2008

2476 Robert Dur and Joeri Sol, Social Interaction, Co-Worker Altruism, and Incentives, November 2008

2477 Gaëtan Nicodème, Corporate Income Tax and Economic Distortions, November 2008

2478 Martin Jacob, Rainer Niemann and Martin Weiss, The Rich Demystified - A Reply to Bach, Corneo, and Steiner (2008), November 2008

2479 Scott Alan Carson, Demographic, Residential, and Socioeconomic Effects on the Distribution of $19^{\text {th }}$ Century African-American Stature, November 2008

2480 Burkhard Heer and Andreas Irmen, Population, Pensions, and Endogenous Economic Growth, November 2008

2481 Thomas Aronsson and Erkki Koskela, Optimal Redistributive Taxation and Provision of Public Input Goods in an Economy with Outsourcing and Unemployment, December 2008

2482 Stanley L. Winer, George Tridimas and Walter Hettich, Social Welfare and Coercion in Public Finance, December 2008

2483 Bruno S. Frey and Benno Torgler, Politicians: Be Killed or Survive, December 2008

2484 Thiess Buettner, Nadine Riedel and Marco Runkel, Strategic Consolidation under Formula Apportionment, December 2008 